\title{
Defects in Breathing and Thermoregulation in Mice with Near-Complete Absence of Central Serotonin Neurons
}

\author{
Matthew R. Hodges, ${ }^{1}$ Glenn J. Tattersall, ${ }^{2}$ Michael B. Harris, ${ }^{3}$ Sean D. McEvoy, ${ }^{1}$ Diana N. Richerson, ${ }^{1}$ Evan S. Deneris, ${ }^{4}$ \\ Randy L. Johnson, ${ }^{5}$ Zhou-Feng Chen, ${ }^{6}$ and George B. Richerson ${ }^{1,7}$ \\ ${ }^{1}$ Departments of Neurology and Cellular and Molecular Physiology, Yale University, New Haven, Connecticut 06520, ${ }^{2}$ Department of Biological Sciences, \\ Brock University, St. Catharines, Ontario, Canada L2S 3A1, ${ }^{3}$ Institute of Arctic Biology, University of Alaska Fairbanks, Fairbanks, Alaska 99775, \\ ${ }^{4}$ Department of Neuroscience, Case Western Reserve University, Cleveland, Ohio 44106, ${ }^{5}$ Department of Biochemistry and Molecular Biology, University of \\ Texas, Houston, Texas 77030, ${ }^{6}$ Departments of Anesthesiology, Psychiatry, Molecular Biology and Pharmacology, Washington University School of \\ Medicine Pain Center, St. Louis, Missouri 63110, and ${ }^{7}$ Veterans Affairs Medical Center, West Haven, Connecticut 06516
}

Serotonergic neurons project widely throughout the CNS and modulate many different brain functions. Particularly important, but controversial, are the contributions of serotonin (5-HT) neurons to respiratory and thermoregulatory control. To better define the roles of 5-HT neurons in breathing and thermoregulation, we took advantage of a unique conditional knock-out mouse in which $\operatorname{Lmx} 1 \mathrm{~b}$ is genetically deleted in Pet1-expressing cells $\left(\operatorname{Lm} x 1 b^{f f / p}\right)$, resulting in near-complete absence of central 5-HT neurons. Here, we show that the hypercapnic ventilatory response in adult $L m \times 1 b^{f f f / p}$ mice was decreased by $50 \%$ compared with wild-type mice, whereas baseline ventilation and the hypoxic ventilatory response were normal. In addition, $L m x 1 b^{f f f / p}$ mice rapidly became hypothermic when exposed to an ambient temperature of $4^{\circ} \mathrm{C}$, decreasing core temperature to $30^{\circ} \mathrm{C}$ within $120 \mathrm{~min}$. This failure of thermoregulation was caused by impaired shivering and nonshivering thermogenesis, whereas thermosensory perception and heat conservation were normal. Finally, intracerebroventricular infusion of 5-HT stimulated baseline ventilation, and rescued the blunted hypercapnic ventilatory response. These data identify a previously unrecognized role of 5 - $\mathrm{HT}$ neurons in the $\mathrm{CO}_{2}$ chemoreflex, whereby they enhance the response of the rest of the respiratory network to $\mathrm{CO}_{2}$. We conclude that the proper function of the 5-HT system is particularly important under conditions of environmental stress and contributes significantly to the hypercapnic ventilatory response and thermoregulatory cold defense.

Key words: 5-HT; chemoreception; carbon dioxide; thermogenesis; respiratory control; temperature

\section{Introduction}

Neurons that produce serotonin (5-HT) are restricted to a small number of nuclei in the brainstem. They project to virtually every region of the CNS, where they influence a broad spectrum of brain functions. They are known to modulate respiration and thermoregulation, but their specific roles in these regulatory systems remain unclear.

5-HT has been shown to influence ventilatory control at many levels of the peripheral nervous system and CNS, and through a variety of mechanisms (Feldman et al., 2003). The effects of 5-HT on breathing are in general modulatory, increasing or decreasing

\footnotetext{
Received 0ct. 18, 2007; revised Jan. 21, 2008; accepted Jan. 21, 2008.

This work was supported by the Parker B. Francis Foundation (M.R.H.), Natural Sciences and Engineering Research Council Grant 262-087-2003 (G.J.T.), National Institute of Mental Health and National Institute of Neurological Disorders and Stroke Office of Minority Health Research Specialized Neurosciences Research Program 5 U54 NS41069-06A1 (M.B.H.), the Yale School of Medicine Summer Research Program (S.D.M.), National Institutes of Health Grants R01MH62723 (E.S.D.), 5 R01NS046036-04 (Z.F.C.), P01HD36379, and HD052772, and the Veteran's Affairs Medical Center (G.B.R.). We thank Yin Jun for developing and troubleshooting the genotyping protocol, and John Sayward for programming support for data collection and analysis.

The authors declare no competing financial interests.

Correspondence should be addressed to Dr. Matthew R. Hodges, Department of Neurology, LCI-704, Yale University School of Medicine, 15 York Street, P.0. Box 208018, New Haven, СT 06520-8018. E-mail: matthew.hodges@yale.edu.

DOI:10.1523/JNEUROSCI.4729-07.2008

Copyright $\odot 2008$ Society for Neuroscience $\quad$ 0270-6474/08/282495-11\$15.00/0
}

the excitability of postsynaptic targets depending on the complement of 5-HT receptors expressed. For example, 5-HT receptor activation facilitates respiratory rhythm generation via $5-\mathrm{HT}_{2 \mathrm{a}}$ and $5-\mathrm{HT}_{4 \mathrm{a}}$ receptors, the former in part via activation of persistent sodium current (Pena and Ramirez, 2002; Manzke et al., 2003). 5-HT also directly enhances excitability of respiratory motor neurons, in part via inhibition of leak $\mathrm{K}^{+}$channels (Larkman and Kelly, 1992; Rekling et al., 2000; Brandes et al., 2006). These neuromodulatory effects generally lead to net stimulation of respiratory output (Richerson, 2004), which is consistent with the observation that specific lesions of 5-HT neurons can cause hypoventilation (Mueller et al., 1984), and instability of respiratory rhythm (Erickson et al., 2007). However, there are data that suggest that 5-HT can inhibit breathing. For example, pharmacologically depleting 5-HT with 6-fluorotryptophan or parachlorophenyalanine (PCPA) increases ventilation, and the PCPA effect partially reverses with 5-HT repletion by L-tryptophan (Olson et al., 1979). There is also evidence that respiratory output, and some respiratory neurons, can be inhibited in vivo by 5 -HT under some conditions (Lalley, 1986).

The specific role of 5-HT neurons in respiratory control is also unclear. 5-HT neurons respond to hypercapnic acidosis with an increase in activity in vitro (Richerson, 1995; Wang et al., 2001), and in vivo (Larnicol et al., 1994; Veasey et al., 1995; Haxhiu et al., 
2001; Johnson et al., 2005), and this causes an increase in 5-HT release in vivo (Kanamaru and Homma, 2007), indicating that 5-HT neurons are modulated by the acid/base status of the brain. There is also evidence for a trophic role for 5-HT, especially during development and after CNS injury (Golder and Mitchell, 2005), as well as a permissive effect for some forms of plasticity such as long-term facilitation of respiratory motor output (Baker-Herman et al., 2004). Thus, the mechanisms of action, specific role, and relative importance of 5-HT and/or 5-HT neurons in respiratory control are complex and remain unclear (Richerson, 2004; Guyenet et al., 2005; Richerson et al., 2005).

The contribution of 5-HT neurons in the regulation of body temperature, particularly under conditions of decreased ambient temperature, has also not been clearly defined. Defense of body temperature during exposure to cold requires heat production (shivering and nonshivering thermogenesis) and conservation (peripheral vasoconstriction). Each of these mechanisms are regulated at different levels of the CNS, and are influenced by 5-HT (Morrison, 2004b; Boulant, 2006; Dimicco and Zaretsky, 2007). Some 5-HT neurons project to the intermediolateral cell column (Cano et al., 2003), and increase their activity in response to both environmental (Martin-Cora et al., 2000) and hypothalamic (Nason and Mason, 2006) cooling. Additionally, systemic or raphé/parapyramidal application of the $5-\mathrm{HT}_{1 \mathrm{~A}}$ receptor agonist 8-hydroxy-2-(di-N-propylamino)tetralin (8-OH-DPAT) decreases core temperature and impairs shivering (Hoffman et al., 2007), inhibits cold-induced vasoconstriction (Ootsuka and Blessing, 2003), and attenuates leptin-evoked activation of brown adipose tissue (BAT) sympathetic outflow (Morrison, 2004a). However, it remains unclear if 5-HT neurons are presympathetic motor neurons that drive thermogenesis and peripheral vasoconstriction, or if they simply modulate descending drive (Nason and Mason, 2006).

What is the specific contribution of 5-HT neurons in breathing and thermoregulation in vivo? Previous studies aiming to address this question have used pharmacologic or lesioning approaches that either lack specificity for, or affect only a subset of, 5-HT neurons (see Discussion). Here, we address this question by characterizing ventilatory and thermoregulatory control mechanisms in adult $L m x 1 b^{f / f / p}$ mice in which there is a nearcomplete $(>99 \%)$ and specific absence of central serotonergic neurons, and marked depletion of central 5-HT (Zhao et al., 2006; Zhao et al., 2007).

\section{Materials and Methods}

Animal model. The generation of $L m x 1 b^{f / f / p}$ mice has been described previously (Zhao et al., 2006). Briefly, homozygous loxP-flanked Lmxlb $\left(L m \times 1 b^{f / f}\right)$ mice were mated with hemizygous ePet-Cre mice to generate Lmxl flox/+;ePet-Cre/+ heterozygous progeny (F1). These F1 mice were then intercrossed to give rise to Lmxl $b^{\text {flox/flox;ePet-Cre/+ }}$ mice, in which both $L m x 1 b$ alleles are excised in, and only in, all ePet-Cre-expressing cells (5-HT neurons). Experiments were performed on 59 adult $[35 \mathrm{fe}-$ male, 20 wild-type (WT) and $15 L m \times 1 b^{f / f / p} ; 24$ male, $13 \mathrm{WT}$ and 11 $L m \times 1 b^{f / f / p}$ ], and 74 neonatal (39 female, $36 \mathrm{WT}$ and $3 L m x 1 b^{f / f / p} ; 35$ male, $31 \mathrm{WT}$ and $4 L m \times 1 b^{f / f / p}$ ) age-matched mice, pairing WT and $L m \times 1 b^{f / f / p}$ littermates in most cases. Genotyping was determined from tail tissue collected from postnatal day 3 (P3)-P10 mice using methods described previously (Zhao et al., 2006). All animals received food and water ad libitum and, were housed and maintained on a $12 \mathrm{~h}$ light/dark cycle in the Yale Animal Resource Center. All protocols approved by the Yale Animal Care and Use Committee.

Surgical instrumentation. Mice were given preoperative analgesia (meloxicam, $1.0 \mathrm{mg} / \mathrm{kg}$, i.p.; or buprenorphine, $0.1 \mathrm{mg} / \mathrm{kg}$, i.p.) before induction and maintenance of anesthesia with $20 \%(\mathrm{v} / \mathrm{v})$ isoflurane
Table 1. Baseline parameters in WT and $L m \times 1 b^{\mathrm{f} / \mathrm{f} / \mathrm{p}}$ mice

\begin{tabular}{|c|c|c|}
\hline Parameter & Wild type & $L m \times 1 b^{f / f / p}$ \\
\hline $\operatorname{Age}(d)$ & $181.3 \pm 14.4$ & $167.9 \pm 17.8$ \\
\hline Body weight (gm) & $31.4 \pm 1.7$ & $27.6 \pm 1.8$ \\
\hline$T_{\text {Core }}\left({ }^{\circ} \mathrm{C}\right)$ & $38.2 \pm 0.2$ & $37.9 \pm 0.3$ \\
\hline$V_{E}\left(\mathrm{ml} \cdot \min ^{-1} \cdot \mathrm{gm}^{-1}\right)$ & $0.74 \pm 0.05$ & $0.68 \pm 0.07$ \\
\hline$F\left(\right.$ breath $\left.\cdot \min ^{-1}\right)$ & $144.5 \pm 4.5$ & $119.2 \pm 7.2^{*}$ \\
\hline$V_{\mathrm{T}}\left(\mu \mathrm{l} \cdot\right.$ breath $\left.^{-1} \cdot \mathrm{gm}^{-1}\right)$ & $5.16 \pm 0.35$ & $5.75 \pm 0.38$ \\
\hline$V_{\mathrm{T}} / T_{\mathrm{I}}\left(\mathrm{ml} \cdot\right.$ breath $\left.^{-1} \cdot \mathrm{s}^{-1}\right)$ & $1.26 \pm 0.09$ & $0.74 \pm 0.52^{* *}$ \\
\hline$V_{0_{2}}\left(\mathrm{mlO}_{2} \cdot \min ^{-1} \cdot \mathrm{g}^{-1}\right)$ & $0.048 \pm 0.004$ & $0.045 \pm 0.004$ \\
\hline$V_{\mathrm{E}} / V_{\mathrm{O}_{2}}$ & $16.3 \pm 1.5$ & $15.7 \pm 1.3$ \\
\hline Arterial pH & $7.305 \pm 0.026$ & $7.299 \pm 0.029$ \\
\hline $\mathrm{P}_{\mathrm{A}} \mathrm{CO}_{2}(\mathrm{mmHg})$ & $41.5 \pm 1.3$ & $42.2 \pm 1.7$ \\
\hline
\end{tabular}

All values are mean $\pm \mathrm{SEM}$. F, Frequency; $V_{\mathrm{T}} / T_{1}$, ventilatory drive. All measurements were obtained while breathing room air at an ambient temperature of $30^{\circ} \mathrm{C}$. Comparisons were made with a unpaired $t$ test. ${ }^{*} p<0.05$; ${ }^{* *} p<$ 0.001 .

mixed with propylene glycol. The abdomen was shaved and sterilized, a midline incision was made, and telemetric temperature probes (Emitter G2; Mini Mitter, Bend, OR) were implanted intraperitoneally and the incision was sutured.

Some mice were instrumented with EEG/EMG head mounts as indicated (Pinnacle Technologies, Lawrence, KS), in which case anesthesia was induced and maintained with ketamine (100 mg/kg, i.p.) and xylazine $(10 \mathrm{mg} / \mathrm{kg}$, i.p.). A midline incision was made in the scalp, and the periosteum was removed. Four screws were passed through the head mount into four predrilled craniotomy holes, and the device was secured with dental acrylic. Two EMG wires from the head mount were sutured onto the nuchal muscles in the back of the neck. The skin was then sutured around the head mount.

Another group of $L m x 1 b^{f / f / p}$ mice received intracerebroventricular cannulas (Alzet Brain Kit III; Durect, Cupertino, CA). Compared with the mice used for the ventilatory measurements described in Table 1 and Figures 1 and 2, the $L m \times 1 b^{f / f / p}$ mice used for cannulation (and their age-matched WT counterparts) were younger (mean age $90 \pm 16 \mathrm{~d}$ compared with $\sim 180 \mathrm{~d}$ ) (Table 1 ). The difference in age may account for small differences in baseline measurements (see below). After induction of anesthesia with ketamine/xylazine, a midline incision was made along the scalp and the periosteum removed. A craniotomy was made above the lateral ventricle $1 \mathrm{~mm}$ caudal and $1 \mathrm{~mm}$ lateral to bregma. Cannulas were prepared by filling osmotic mini pumps (Alzet model 1003D; Durect) with artificial CSF containing (in $\mathrm{mm}$ ) $124 \mathrm{NaCl}, 3 \mathrm{KCl}, 2 \mathrm{CaCl}_{2}, 2 \mathrm{MgCl}_{2}$, $26 \mathrm{NaHCO}_{3}, 1.3 \mathrm{NaH}_{2} \mathrm{PO}_{4}, 10$ dextrose, $\mathrm{pH} 7.4$, bubbled with 5\% $\mathrm{CO}_{2}$, to which serotonin $\mathrm{HCl}$ was added at the appropriate concentration. Each infused solution required a new pump filled with a different concentration of 5-HT. Pump exchanges were also performed under ketamine/xylazine anesthesia. After filling the pumps, they were connected to the cannulas and primed in warmed, sterile saline for $>4 \mathrm{~h}$ before implantation. Cannula were passed through the craniotomy hole to a preset depth below the skull surface $(2-2.5 \mathrm{~mm})$, secured with adhesive (Loctite 454; Henkel, Düsseldorf, Germany), and covered with dental acrylic. The pumps were tunneled under the skin over the back, and the incision was sutured over the acrylic. Mice received $1.7 \mu \mathrm{g} / \mathrm{ml}$ meloxicam in drinking water for $2 \mathrm{~d}$, and then studied $>7 \mathrm{~d}$ after implantation, or $2 \mathrm{~d}$ after pump exchange.

Plethysmography. Ventilation was measured using standard plethysmographic techniques (Drorbaugh and Fenn, 1955) in a custom-made chamber $(250 \mathrm{ml})$ with continuous gas flow $(700 \mathrm{ml} / \mathrm{min})$ set on top of the telemeter energizer/receiver (model ER-4000; Mini Mitter). Compressed gas mixtures contained either (1) $21 \% \mathrm{O}_{2}$, balance $\mathrm{N}_{2}$ with $0,3,5$, or $7 \% \mathrm{CO}_{2}$ (normoxic hypercapnia); (2) $50 \% \mathrm{O}_{2}$, balance $\mathrm{N}_{2}$ with $0,3,5$, or $7 \% \mathrm{CO}_{2}$ (hyperoxic hypercapnia) or; (3) $10 \% \mathrm{O}_{2}$, balance $\mathrm{N}_{2}$ (hypoxia). Hypercapnia studies consisted of $>20$ min of baseline, followed by 10 min exposures to 3, 5, and 7\% $\mathrm{CO}_{2}$, each separated by $10 \mathrm{~min}$ baseline measurements. Similarly, hypoxia studies consisted of $>20 \mathrm{~min}$ of baseline followed by $10 \mathrm{~min}$ of $10 \% \mathrm{O}_{2}$. Oxygen consumption was calculated by subtracting the outflow fraction of $\mathrm{O}_{2}$ from the inflow fraction of $\mathrm{O}_{2}$ measured with an $\mathrm{O}_{2}$ analyzer (model S3A/I; AEI Technologies, Naper- 
ville, IL), and multiplying the difference by the chamber flow rate. Air temperature and relative humidity (HX-93AV; Omega Engineering, Stamford, CT), breathing-induced pressure oscillations (DC002NDR5; Honeywell International, Morristown, $\mathrm{NJ}$ ), $\mathrm{O}_{2}$ and $\mathrm{CO}_{2}$ concentrations [model CD-3A $\left(\mathrm{CO}_{2}\right)$; AEI Technologies], and animal temperature (emitter G2; Mini Mitter) were measured continuously at $100 \mathrm{~Hz}$, digitized using an analog-to-digital converter (PCI-6221; National Instruments, Austin, TX), and acquired by a data acquisition program customwritten in Matlab (The MathWorks, Natick, MA).

There are inherent problems in ventilatory measurements, particularly in small mammals (Mortola and Frappell, 1998). To minimize these confounding factors, we used a small, custom-made plethysmograph with a time constant of $>5.0$ s to measure the relatively small ventilatory pressure changes generated by mice. Breathing-induced pressure changes were calibrated with $0.1 \mathrm{ml}$ pulses using a $1 \mathrm{ml}$ syringe at a frequency near that of resting breathing $(2 \mathrm{~Hz})$. Additionally, because of the dependence of tidal volume calculations on temperature and $\mathrm{Q}^{10}$ effects on ventilation (Cooper and Veale, 1986), as well as the deficits in thermoregulation in the $L m x 1 b^{f / f / p}$ mice, all plethysmographic studies were performed at ambient temperatures within the thermoneutral zone for mice (Gordon, 1985), and animal temperature was measured in all cases to determine any differences in animal temperature (Table 1).

All ventilatory data were collected and analyzed off-line using customwritten software (Matlab; The MathWorks) by an individual blind to animal genotypes. All ventilatory data segments of $6-10 \mathrm{~s}$ duration that did not contain sighs, coughs, sniffing or movement artifacts were selected for analysis from the second half of each 10-min period of gas exposure during the baseline and hypercapnia studies. Hypoxia data were analyzed during minutes $2-10$ of the $10 \mathrm{~min}$ exposure, and binned into 2 min means to evaluate the time course of the response. Because 5-HT has long been linked to sleep, we only used data when the animals were awake by restricting analyzed data segments to time periods $<30 \mathrm{~s}$ after motor activity (Pack et al., 2007), and when the animals eyes were open. There was no difference in ventilation between the first $10 \mathrm{~s}$ after motor activity and seconds $10-30$, indicating that mice were not rapidly falling asleep after movement ceased, consistent with behavioral observations. Our experimental design did not allow us to evaluate differences in the effects of 5-HT neuron loss on respiratory control during sleep versus wakefulness.

Arterial blood gas measurements. Blood gases and arterial $\mathrm{pH}$ were measured in WT and $L m \times 1 b^{f / f / p}$ mice. Mice received heparin (20 U, i.p.) $30 \mathrm{~min}$ before induction of anesthesia with isoflurane $(20 \% \mathrm{v} / \mathrm{v}$ in propylene glycol) in room air. The abdomen was opened, and a 25 -gauge needle attached to a $1 \mathrm{ml}$ syringe was passed through the diaphragm into the left ventricle. 200-550 $\mu \mathrm{l}$ of blood was withdrawn, and arterial $\mathrm{pH}$, $\mathrm{PCO}_{2}, \mathrm{PO}_{2}, \mathrm{HCO}^{3-}$, base excess (BEecf), $\mathrm{TCO}_{2}$, and $\mathrm{O}_{2}$ saturation measured using I-STAT $\mathrm{G}^{+}$cartridges and a blood gas analyzer (Abbott Laboratories, North Chicago, IL). Samples were rejected if $\mathrm{O}_{2}$ saturation was $<90 \%$. Duplicate measurements were made from single samples with high concordance. Using this approach, arterial $\mathrm{PCO}_{2}$ would be elevated compared with measurements from awake mice. However, a metabolic acidosis or alkalosis would still be reflected in the blood gases, and would help to determine if there was any compensation of chronic changes in ventilation (see also Results). The resulting measurements ( $n=6$ for each group) were as follows: $\mathrm{PO}_{2}=75.6 \pm 3.4$ (WT) and $89.9 \pm 4.5\left(\operatorname{Lmx} 1 b^{f / f / p}\right), \mathrm{O}_{2}$ saturation $=93.1 \pm 1.2(\mathrm{WT})$ and $95.3 \pm 0.9$ $\left(L m \times 1 b^{f / f / p}\right), \mathrm{HCO}_{3}=20.7 \pm 1.0(\mathrm{WT})$ and $20.8 \pm 1.2\left(\operatorname{Lm} \times 1 b^{f / f / p}\right)$, BEecf $=-5.5 \pm 1.6(\mathrm{WT})$ and $-5.5 \pm 1.4\left(\mathrm{Lm} \times 1 b^{f / f / p}\right)$, and $\mathrm{TCO}_{2}=$ $21.8 \pm 1.0(\mathrm{WT})$ and $22.2 \pm 1.2\left(\mathrm{Lm} \times 1 b^{f / f / p}\right)$. Arterial $\mathrm{pH}$ and $\mathrm{PCO}_{2}$ means are shown in Table 1.

Twenty-four hour temperature and activity measurements. Mice instrumented with abdominal telemetric temperature probes were placed in mouse cages containing food, water bottles and bedding, and the cages were placed on top of the telemeter receiver. Core temperature, motor activity (detected as a change in location by the telemetric receiver) and ambient temperature were collected every 10 seconds for $24 \mathrm{~h}$ at ambient temperatures of 24 or $30^{\circ} \mathrm{C}$. Studies began at 7:00 A.M. when the lights were turned on, and the lights were turned off at 7:00 P.M. until studies were terminated the following morning at 7:00 A.M.
Cold challenges. Mice instrumented with abdominal telemetric temperature probes were placed in mouse cages devoid of bedding or food, and placed on top of the telemeter energizer/receiver. The equipment was wheeled from a warm environment into a cold room set to either 12 or $4^{\circ} \mathrm{C}$. Ambient and animal temperatures, and motor activity were recorded for $4-7 \mathrm{~h}$. Some animals were removed from the cold room early because of marked hypothermia (see Fig. $3 C-F$ ). Using this same technique, mice instrumented with EEG/EMG head mounts were connected to a computerized data acquisition system via a commutator. Nuchal EMG, core temperature and motor activity were recorded before $\left(28^{\circ} \mathrm{C}\right)$, during, and after a cold challenge $\left(4^{\circ} \mathrm{C}\right)$, and the animal was videotaped to differentiate shivering from movement artifact. EMG data were collected at a rate of $400 \mathrm{~Hz}$. This was converted to root mean square (RMS) activity using 20 -point bins with $50 \%$ overlap, resulting in conversion to a rate of 40 points per second. RMS activity was analyzed for bursting (shivers) in $10 \mathrm{~s}$ epochs after smoothing with a four-point moving average method. A burst was defined when RMS activity exceeded a threshold (set at $5 \mu \mathrm{V}$ above the baseline level) for at least $250 \mathrm{~ms}$, and the duration of individual bursts was defined as the time above the threshold. The baseline level was defined as the mean of the lowest $25 \%$ of RMS data points for each $10 \mathrm{~s}$ epoch. The frequency of bursts was plotted versus time using Origin software (OriginLab, Northampton, MA) with adjacent averaging.

Additional cold challenges for thermal imaging were performed on adult and neonatal mice in a custom-made thermal chamber containing a telemetric receiver, radiator and fan. Water was circulated through the radiator with a pump and its temperature was controlled with a submersible heater or by adding ice. A port was cut into the top (for BAT experiments) or bottom (for tail/paw blood flow experiments) of the thermal chamber for insertion of a calibrated thermographic camera (model 7515; Mikron Infrared, Oakland, NJ). Thermographic images (1 frame/10 s) were collected with a computer using imaging software (Mikrospec RT; Mikron Infrared, Oakland, NJ), and surface temperatures were analyzed off-line. Mean tail surface temperatures were obtained along a line drawn over the tail midline, from the proximal third to the distal third, and mean ambient temperature obtained from a circle drawn over the background surface in each 10th image (every $100 \mathrm{~s}$ ). Similarly, mean skin surface temperatures overlying intrascapular BAT (IBAT) tissue and the lower back were obtained using two equally shaped ovals. Thermographic data were obtained from neonates initially housed at neutral temperature $\left(35^{\circ} \mathrm{C}\right)$ and during a rapid $(30 \mathrm{~min})$ cold challenge to $20^{\circ} \mathrm{C}$.

IBAT function was tested in a subset of chloralose-anesthetized mice warmed with a heating pad. A thermocouple was implanted in the IBAT, and the skin sutured. After 5-10 min of control recording, norepinephrine $(2.0 \mathrm{mg} / \mathrm{kg}$, i.p.) was injected and IBAT temperature was recorded every $2 \mathrm{~min}$ for $30 \mathrm{~min}$. Thermographic images of the shaved skin temperature overlying the IBAT were obtained in a subset of mice to confirm that measurement of changes in skin temperature overlaying IBAT accurately reflected changes in temperature within the IBAT itself. Intrascapular brown fat pads were extracted and wet weights determined.

Thermosensory perception was tested by placing mice into one of four lanes on top of a sheet of copper covered with heat transfer tape with lines drawn perpendicular to the lanes across the plate, subdividing the sheet into 20 distinguishable, equally sized sections. The copper sheet was heated at one end with a hot plate $\left(\sim 40^{\circ} \mathrm{C}\right)$ and cooled at the other end with a Peltier thermal transfer device $\left(\sim 10^{\circ} \mathrm{C}\right)$, creating a linear, thermal gradient (see Fig. $4 \mathrm{~A}$ ). Animals were videotaped over a $2.5 \mathrm{~h}$ period, and the location of the animal was recorded every $2 \mathrm{~min}$, allowing for the assessment of selected ambient temperature.

Statistics. Interactions of genotype and condition (or time) were analyzed on all physiologic variables using a two-way ANOVA, paired $t$ test, or two-tailed $t$ test assuming unequal variance when appropriate (significance threshold, $p<0.05$ ).

\section{Results}

Marked impairment in the ventilatory $\mathrm{CO}_{2}$ response

In slices of the neonatal rat medulla, respiratory rhythm generation is dependent on input from serotonergic raphé neurons 
(Pena and Ramirez, 2002; Pace et al., 2007). Raphé lesions in adult goats induce central apnea in vivo (Hodges et al., 2004b). In addition, Pet1 null mice with a $70 \%$ decrease in number of 5-HT neurons exhibit greater variability of respiratory output during the neonatal period (Erickson et al., 2007). However, we did not observe severely altered breathing patterns, such as prolonged apnea or ataxic breathing, in adult $L m \times 1 b^{f / f / p}$ mice under baseline conditions. There was increased duration of inspiration and an $18 \%$ reduction in baseline respiratory frequency in $L m \times 1 b^{f / f / p}$ mice, but minute ventilation was unchanged because of a trend toward greater $(p=0.0627)$ tidal volume (Table 1). Arterial blood gases and $\mathrm{pH}$ were not different between genotypes, indicating that there is not compensation by chronic metabolic acid/base changes (assessed by BEecf) (Table 1) (Materials and Methods). There also was a trend toward an increase in the SD of the interbreath interval (IBI), hinting at greater breath-tobreath variability in $L m \times 1 b^{f / f / p}$ mice ( $p=$ 0.063 ). Indeed, Poincaré analyses showed greater short- and long-term variability in the IBI (Fig. $1 A-C$ ). However, variability in biological rhythms is often higher at lower frequencies, and vice versa (Ivanov et al., 1996). We plotted short-term variability (width) as a function of breathing frequency in WT mice and found that variability was described by the equation: variability $=14,660 \times$ frequency $^{-2.4754}$ (Fig. 1D). Data from $L m \times 1 b^{f / f / p}$ mice were accurately described by the same function, indicating that the increased breath-to-breath variability was not attributable to instability of respiratory rhythm per se. Additionally, the ratio of tidal volume to inspiratory time (or slope of the inspiratory phase, an index of ventilatory "drive") was reduced $(-41.1 \%)$ in $L m \times 1 b^{f / f / p}$ mice (Table 1). Thus, 5-HT neurons are not required for respiratory rhythm generation or stability in vivo, but increase respiratory frequency and contribute significantly to ventilatory drive.

In light of the evidence supporting a role for 5-HT neurons in the hypercapnic ventilatory response (HCVR) (Richerson et al., 2001; Wang et al., 2001; Severson et al., 2003; Hodges et al., 2004a; Nattie et al., 2004), we challenged WT and $L m x 1 b^{f / f / p}$ mice with an increase in ambient $\mathrm{CO}_{2}$. This was done under both normoxic $\left(21 \% \mathrm{O}_{2}\right)$ and hyperoxic $\left(50 \% \mathrm{O}_{2}\right)$ conditions, because the latter attenuates the contribution of peripheral chemoreceptors to the HCVR (Lahiri and DeLaney, 1975). Minute ventilation $\left(V_{\mathrm{E}}\right)$ in $L m \times 1 b^{f / f / p}$ mice was significantly reduced compared with WT mice during normoxic hypercapnia (Fig. $2 A-C$ ). The increase in $V_{\mathrm{E}}\left(\Delta V_{\mathrm{E}} / g\right)$ was $44.8 \%$ less breathing $5 \% \mathrm{CO}_{2}$, and $40.0 \%$ less breathing $7 \% \mathrm{CO}_{2}$ (Fig. $2 \mathrm{~B}$ ). There were no differences in oxygen consumption $\left(V_{\mathrm{O}_{2}}\right)$, and as a result the increase in the convection requirement $\left(V_{\mathrm{E}} / V_{\mathrm{O}_{2}}\right)$ was also significantly reduced in $L m \times 1 b^{f / f / p}$ relative to WT mice breathing $5 \%(18.4 \pm 2.9$ vs $26.8 \pm 2.5$; $-31.6 \%)$ and $7 \% \mathrm{CO}_{2}(28.5 \pm 3.5$ vs $43.6 \pm 3.5$; $-34.6 \%$; twoway ANOVA; $p=0.002$ ). Hyperoxia caused a trend toward a decrease in baseline ventilation in WT and $L m \times 1 b^{f / f / p}$ mice, which would be expected with suppression of peripheral chemoreceptor input. In hyperoxia, the increase in $V_{\mathrm{E}}\left(\Delta V_{\mathrm{E}} / g\right)$ was $50.1 \%$ less breathing $5 \% \mathrm{CO}_{2}$, and $52.3 \%$ less breathing $7 \% \mathrm{CO}_{2}$ in $L m \times 1 b^{f / f / p}$ mice compared with WT mice (Fig. $2 B$ ). Hyperoxia attenuated the HCVR in $L m \times 1 b^{f / f / p}$ mice by $18 \%$ relative to normoxia, but had no effect in WT mice. This may indicate a greater reliance on peripheral chemoreceptors in $L m \times 1 b^{f / f / p}$ mice, possibly resulting from developmental compensation. Thus, hyperoxia accentuated the difference in the HCVR between the two genotypes, with the HCVR $50 \%$ lower in $L m x 1 b^{f / f / p}$ mice compared with WT mice (Fig. $2 B$ ). The attenuated HCVR in $L m \times 1 b^{f / f / p}$ mice was solely attributable to a decreased frequency response (Fig. 2C), and both WT and $L m \times 1 b^{f / f / p}$ mice increased tidal volume to equal degrees at all levels of hypercapnia $(p>0.05)$ (data not shown). The deficit in ventilatory drive observed at baseline also persisted in $L m \times 1 b^{f / f / p}$ mice during hypercapnia (data not shown).

In contrast to the large deficit in the HCVR, $L m \times 1 b^{f / f / p}$ mice had a normal response to an acute hypoxic challenge. Ventilation (Fig. 2D), tidal volume, and breathing frequency increased, and inspiratory and expiratory times decreased equally in both groups of mice during hypoxia (data not shown). Rodents, in particular, respond to hypoxia by decreasing $\mathrm{O}_{2}$ consumption (Frappell et al., 1992) and, thus, an important measure of the hypoxic response is the $V_{\mathrm{E}} / V_{\mathrm{O}_{2}}$ ratio. We found no differences between WT and $L m \times 1 b^{f / f / p}$ mice in $\mathrm{O}_{2}$ consumption or $V_{\mathrm{E}} / V_{\mathrm{O}_{2}}$ (expressed as \% control), further indicating that there was no effect on the ventilatory response to acute hypoxia (Fig. 2E). These observations parallel the effects of 8-OH-DPAT microdialysis in the midline raphe of rats in vivo, which decreases the HCVR but has no effect on the hypoxic ventilatory response (Taylor et al., 2005). Our data do not, however, address the importance of 5-HT in other hypoxia-induced respiratory phenom- 
A

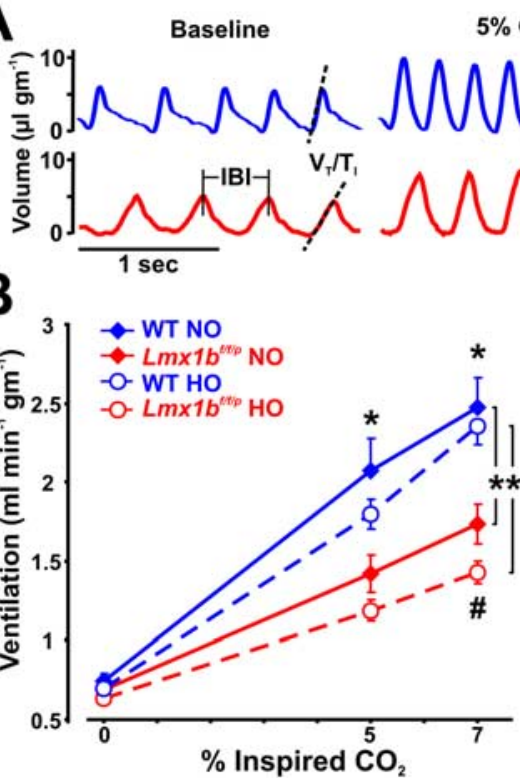

D

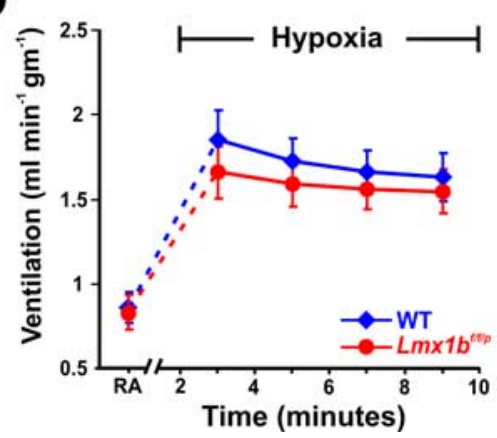

$5 \% \mathrm{CO}_{2}$

M

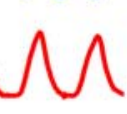

C
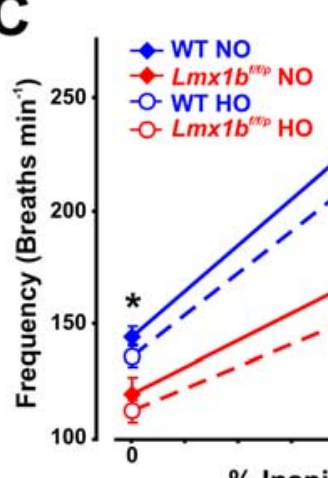

$7 \% \mathrm{CO}_{2}$

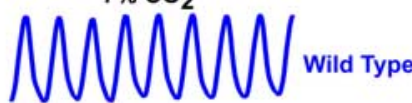

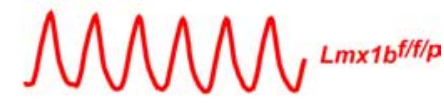

E

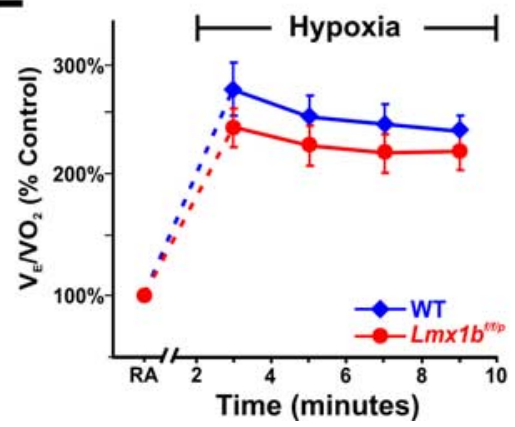

Figure 2. $L m \times 1 b^{f / f / p}$ mice have decreased ventilatory drive and their hypercapnic ventilatory response is severely blunted. $\boldsymbol{A}$, Plethysmography recordings from WT (blue) and $L m \times 1 b^{f / f / p}$ (red) mice at rest, and while breathing $5 \%$ and $7 \% \mathrm{CO}_{2}$ in normoxia $\left(21 \% \mathbf{O}_{2}\right)$. Dashed lines highlight decreased slope of the inspiratory phase (ventilatory drive), and vertical lines mark the IBI. $\boldsymbol{B}, \boldsymbol{C}$, Ventilation ( $\boldsymbol{B}$ ) and breathing frequency ( $\boldsymbol{C}$ ) during hypercapnia under normoxic (NO) and hyperoxic $\left(\mathrm{HO} ; 50 \% 0_{2}\right) \operatorname{conditions}(n=$ 10 WT N0, $8 \mathrm{Lmx} 1 b^{f / f / p}$ N0, 11 WT H0, $8 \mathrm{Lm} x 1 b^{f / f / p}$ HO). $\boldsymbol{D}, \boldsymbol{E}$, Ventilation $(\boldsymbol{D})$ and convection requirement $\left(\boldsymbol{E} ; V_{\mathrm{E}} / V_{0} ;\right.$ expressed as a percentage of control) during exposure to room air (RA) and hypoxia $\left(n=8 \mathrm{WT}, 8 \mathrm{Lm} \times 1 b^{f / f / p}\right)$. For two-way ANOVA (genotype and condition as factors), ${ }^{* *} p<0.05$. For unpaired $t$ test, ${ }^{*} p<0.05$ (WT versus $L m x 1 b^{f / f / p}$ ) for both normoxia and hyperoxia. For paired $t$ test, ${ }^{\#} p<0.05$ for normoxia versus hyperoxia in $L m \times 1 b^{f / f / p}$. Data are mean \pm SEM.

ena, such as long-term facilitation of phrenic motor output after intermittent hypoxia (Baker-Herman and Mitchell, 2002).

\section{Thermoregulatory failure during cold challenge}

Breathing, metabolic rate, and body temperature maintenance are interrelated, and each is known to be influenced by $5-\mathrm{HT}$ neurons. Therefore, we evaluated the importance of 5-HT neuron loss in temperature control. We measured core body temperature $\left(T_{\text {Core }}\right)$ and activity over $24 \mathrm{~h}$ with a normal light/dark cycle at ambient temperatures $\left(T_{\mathrm{Amb}}\right)$ of $24^{\circ} \mathrm{C}$ and $30^{\circ} \mathrm{C}$. WT and $L m \times 1 b^{f / f / p}$ mice both exhibited significant phase-related (circadian) increases in $T_{\text {Core }}$ during the dark compared with light phase at both $T_{\text {Amb }}$ (Fig. $3 A, B$ ). Interestingly, $T_{\text {Core }}$ was $0.9^{\circ} \mathrm{C}$ greater during the dark phase in $L m \times 1 b^{f / f / p}$ mice compared with WT mice at $24^{\circ} \mathrm{C}$. $L m \times 1 b^{f / f / p}$ mice also displayed a threefold greater increase in activity during this time (Fig. $3 A, B$ ), and both WT and $L m \times 1 b^{f / f / p}$ mice showed transient increases in $T_{\text {Core }}$ in individual animals after periods of physical activity (data not shown). The activity of $L m \times 1 b^{f / f / p}$ mice during the dark phase was lower when $T_{\mathrm{Amb}}=30^{\circ} \mathrm{C}$ compared with $24^{\circ} \mathrm{C}$, but remained elevated relative to the light phase (Fig. $3 B$ ). Overall, these results indicate that $L m \times 1 b^{f / f / p}$ mice maintain normal $T_{\text {Core }}$ and display hyperactivity during the active (dark) phase at both 24 and $30^{\circ} \mathrm{C}$. It remains unclear whether the increased activity is a result of a phasespecific "resetting" of the preoptic area neurons that determine basal body temperature (Huttunen et al., 1988), or a primary behavioral effect attributable to the absence of forebrain 5-HT. The apparent hyperactivity is consistent with data from serotonin-depleted mice, which exhibit increased locomotor activity in open field testing and increased mobility in the forced swim test (Uchida et al., 2005).

We then challenged WT and $L m \times 1 b^{f / f / p}$ mice with decreased $T_{\text {Amb }}$ to determine whether 5-HT neurons are important for heat generation or conservation. WT mice maintained $T_{\text {Core }}$ within $1.8^{\circ} \mathrm{C}$ of baseline over a 4 -h period at $4^{\circ} \mathrm{C}$ (Fig. $3 \mathrm{C}$ ), and within $1.5^{\circ} \mathrm{C}$ of baseline over a $7 \mathrm{~h}$ period at $12^{\circ} \mathrm{C}$ (Fig. $3 E$ ). However, $T_{\text {Core }}$ of $L m \times 1 b^{f / f / p}$ mice dropped within $2 \mathrm{~h}$ of exposure to $4^{\circ} \mathrm{C}$, requiring all mice to be removed from the cold before the $4 \mathrm{~h}$ endpoint because of marked hypothermia (Fig. 3D). Similarly, three of seven $L m \times 1 b^{f / f / p}$ mice needed to be removed before the $7 \mathrm{~h}$ endpoint during exposure to $12^{\circ} \mathrm{C}$ (Fig. $3 F$ ), whereas the other four were able to maintain $\mathrm{T}_{\text {Core }}$ above $30^{\circ} \mathrm{C}$. Coupled with the relatively normal $T_{\text {Core }}$ at $T_{\text {Amb }}$ of 24 and $30^{\circ} \mathrm{C}$, respectively, this indicates that $L m \times 1 b^{f / f / p}$ mice retain some thermoregulatory capacity, although it is not sufficient to respond to a moderate cold challenge.

Cold exposure induces behavioral responses such as huddling in a curled posture, and seeking a warmer locale. WT and $L m \times 1 b^{f / f / p}$ mice exhibited similar stationary huddling behavior, suggesting that both can "sense" cold. Consistent with this observation, when WT and $L m \times 1 b^{f / f / p}$ mice were placed on a thermal gradient $\left(\right.$ range $\left.=10-40^{\circ} \mathrm{C}\right)($ Fig. $4 A)$, there were no differences in the amount of time spent at each temperature or the mean temperature selected (Fig. 4B). Thus, the behavioral response of $L m \times 1 b^{f / f / p}$ mice to cold is similar to that of WT mice, indicating normal thermosensory perception.

Vasodilatation or vasoconstriction of the tail, the major heat exchange organ in rodents, regulates heat loss or conservation with changing $T_{\mathrm{Amb}}$. We used thermographic imaging to determine whether a defect in tail vasoconstriction contributed to the cold-induced hypothermia. Tail surface temperatures, measured as a surrogate of blood flow, increased equally during warming $\left(33-36^{\circ} \mathrm{C}\right)$, indicating $L m \times 1 b^{f / f / p}$ mice were capable of vasodilation and heat loss (Fig. 4C). During cooling, tail surface temperatures declined equally in WT and $L m \times 1 b^{f / f / p}$ mice, falling to $1-2^{\circ} \mathrm{C}$ above ambient temperature (Fig. $4 D$ ). Similar results were obtained with measurements of rear paw surface temperatures (data not shown). Thus, $L m \times 1 b^{f / f / p}$ mice exhibited normal peripheral vasoconstrictor responses to cold. This result also indicates that $L m \times 1 b^{f / f / p}$ mice sense ambient and core body tempera- 
ture normally, because the vasoconstrictor response requires normal detection of hypothermia.

Impaired shivering and BAT activation Intact heat conservation in $L m \times 1 b^{f / f / p}$ mice suggests that the cold-induced hypothermia was caused by impaired heat generation. We assessed shivering in WT and $L m \times 1 b^{f / f / p}$ mice by measuring nuchal muscle EMG activity at $T_{\text {Amb }}$ of $28^{\circ} \mathrm{C}$ (warm) and $4^{\circ} \mathrm{C}$ (cold). WT and $L m x 1 b^{f / f / p}$ mice both exhibited low total EMG activity in warm conditions, and increased total EMG activity in the cold (Fig. 5A,B). This measure includes both bursting (shivering) and tonic muscle activity, both of which increase in the cold. The increase $(\Delta)$ in total EMG from warm to cold was less in $L m \times 1 b^{f / f / p}(1.76 \pm 0.29)$ compared with WT $(3.53 \pm 0.41)$ mice $(p=0.016)$ (Fig. $5 B$, top inset). Burst analysis revealed that $L m \times 1 b^{f / f / p}$ mice produced significantly fewer bursts (Fig. 5B). There was a trend toward a longer duration of individual bursts, but this did not reach statistical significance ( $p=0.08$ ) (Fig. $5 B$, bottom inset). These data suggest that $L m \times 1 b^{f / f / p}$ mice have a defect in generation of the bursting pattern typical of normal shivering, which is likely to be important for heat production.

In addition to shivering, small mammals also generate heat by activating BAT metabolism, which involves raphé/parapyramidal sympathetic premotor neurons (Morrison, 2004b). Thermographic images were obtained of bare skin along shaved backs of WT and $L m x 1 b^{f / f / p}$ mice during cooling to determine whether there was impaired activation of IBAT (Fig. 5C). We measured skin surface temperatures from the IBAT region relative to the lower back as an index of IBAT activation (Fig. 5D). The temperature difference in $L m \times 1 b^{f / f / p}$ mice (3.9 \pm $\left.0.4^{\circ} \mathrm{C}\right)$ was not different from that in WT mice $\left(4.3 \pm 0.4^{\circ} \mathrm{C}\right)$ when initially cooled to a $T_{\mathrm{Amb}}$ of $10^{\circ} \mathrm{C}$, consistent with normal IBAT activation (Fig. 5D). However, this differential was attenuated in $L m \times 1 b^{f / f / p}\left(2.7 \pm 0.2^{\circ} \mathrm{C}\right)$ relative to WT $(4.9 \pm$ $0.4^{\circ} \mathrm{C}$ ) mice when cooled further to a $T_{\mathrm{Amb}}$ of $7^{\circ} \mathrm{C}$, indicating a failure to sustain robust IBAT activation during prolonged cold exposure.

The defect in sustained IBAT activation was not caused by smaller IBAT mass, as wet weights of IBAT were not different $(5.7 \pm$ 0.5 in WT, $n=6$, and $5.1 \pm 0.7$ in $L m x 1 b^{f / f / p}, n=6$, mice; expressed as gram IBAT $/ \mathrm{kg}$ animal weight; $p=0.54$ ). Additionally, intrinsic IBAT function was not impaired, as activation by systemic norepinephrine $(2.0 \mathrm{mg} / \mathrm{kg}$, i.p.) produced an equivalent increase in IBAT temperature (measured directly; $3.3 \pm 0.8^{\circ} \mathrm{C}$, WT vs $3.2 \pm 0.6^{\circ} \mathrm{C}$, $L m \times 1 b^{f / f / p}$ ) and skin surface temperature over IBAT (data not shown) in anesthetized $L m \times 1 b^{f / f / p}$ and WT mice. These latter experiments also validated our use of thermography of the skin as a sur-
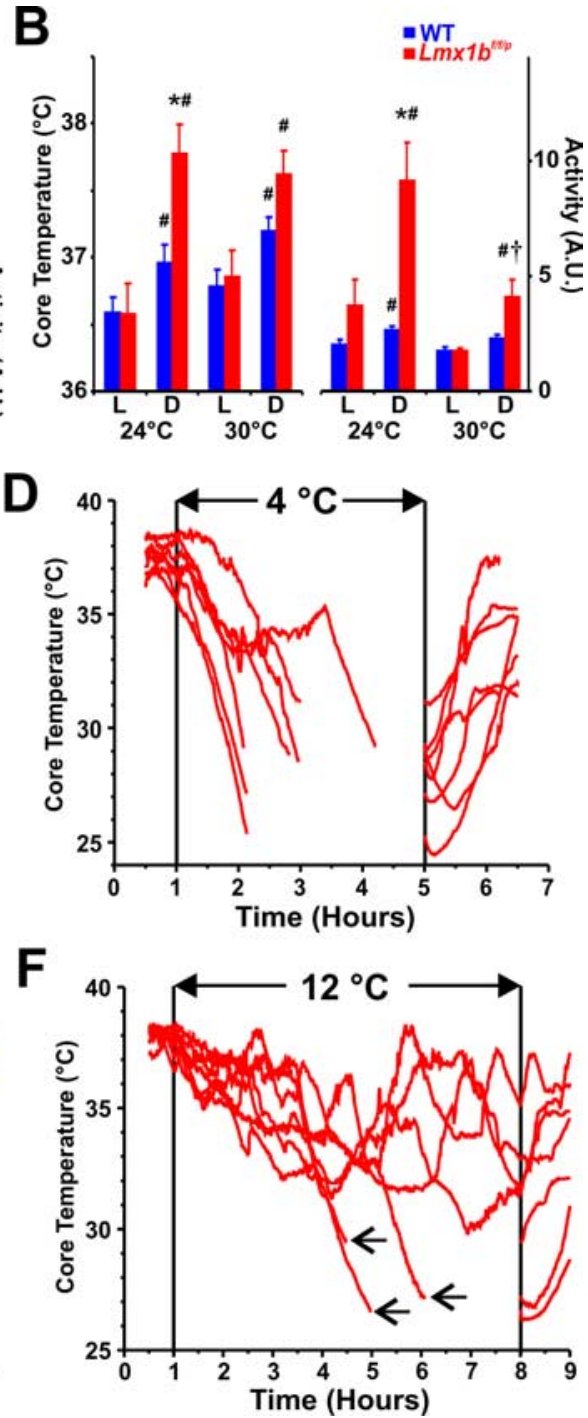

Figure 3. $L m \times 1 b^{f / f / p}$ mice fail to maintain their body temperature during cold exposure. $\boldsymbol{A}$, mean core body temperature $\left(T_{\text {Core }}\right.$ top) and activity [arbitrary units (A.U.); bottom] over $24 \mathrm{~h}$ in WT (blue) and $L m \times 1 b^{f / f / p}$ (red) mice at $24^{\circ} \mathrm{C} . \boldsymbol{B}$, Mean $T_{\text {Core }}$ and activity by phase [light (L); dark (D)] at $24^{\circ} \mathrm{C}\left(n=6 \mathrm{WT}, 5 \mathrm{Lm} \times 1 b^{\mathrm{f} / f / p}\right)$ and $30^{\circ} \mathrm{C}\left(n=6 \mathrm{WT}, 6 \mathrm{Lm} \times 1 b^{\mathrm{f} / f / p}\right) . \mathbf{C}-\boldsymbol{F}$, Core temperatures $\left(T_{\text {Core }}\right)$

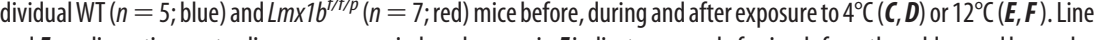
in $\boldsymbol{D}$ and $\boldsymbol{F}$ are discontinuous to align recovery period, and arrows in $\boldsymbol{F}$ indicate removal of animals from the cold caused by marked hypothermia. Unpaired $t$ test was used; ${ }^{*} p<0.05$ for WT versus $L m x 1 b^{f / f / p}$; ${ }^{\#} p<0.05$ for light versus dark; ${ }^{\dagger} p<0.05$ for $24^{\circ} \mathrm{C}$ versus $30^{\circ} \mathrm{C}$. Data are mean $\pm \mathrm{SEM}$.

rogate of IBAT activation during cold exposure, because increases in IBAT temperature were faithfully detected as increases in temperature of the skin surface temperature. Similarly, when $L m \times 1 b^{f / f / p}$ pups (P1 to P6) were exposed to a drop in $T_{\mathrm{Amb}}$ from 35 to $20^{\circ} \mathrm{C}$, they showed a more constant thermal profile along the dorsal skin than WT pups, and they had lower surface temperatures (Fig. $5 E, F$ ). This was significant at the older ages studied ( $p<0.0005$ for P5-P6) when BAT activation is more crucial to neonatal thermostasis. Thus, 5-HT neuron loss led to impairment of sustained activation of IBAT during cold exposure in neonatal and adult $L m \times 1 b^{f / f / p}$ mice, consistent with the concept that central 5-HT supports, but is not required for IBAT activation (Madden and Morrison, 2006). Together, defects in sustained and coordinated shivering and IBAT activation combine to cause severe impairment of thermoregulatory defense against a cold challenge, without loss of temperature control in adults under unstressed conditions. 

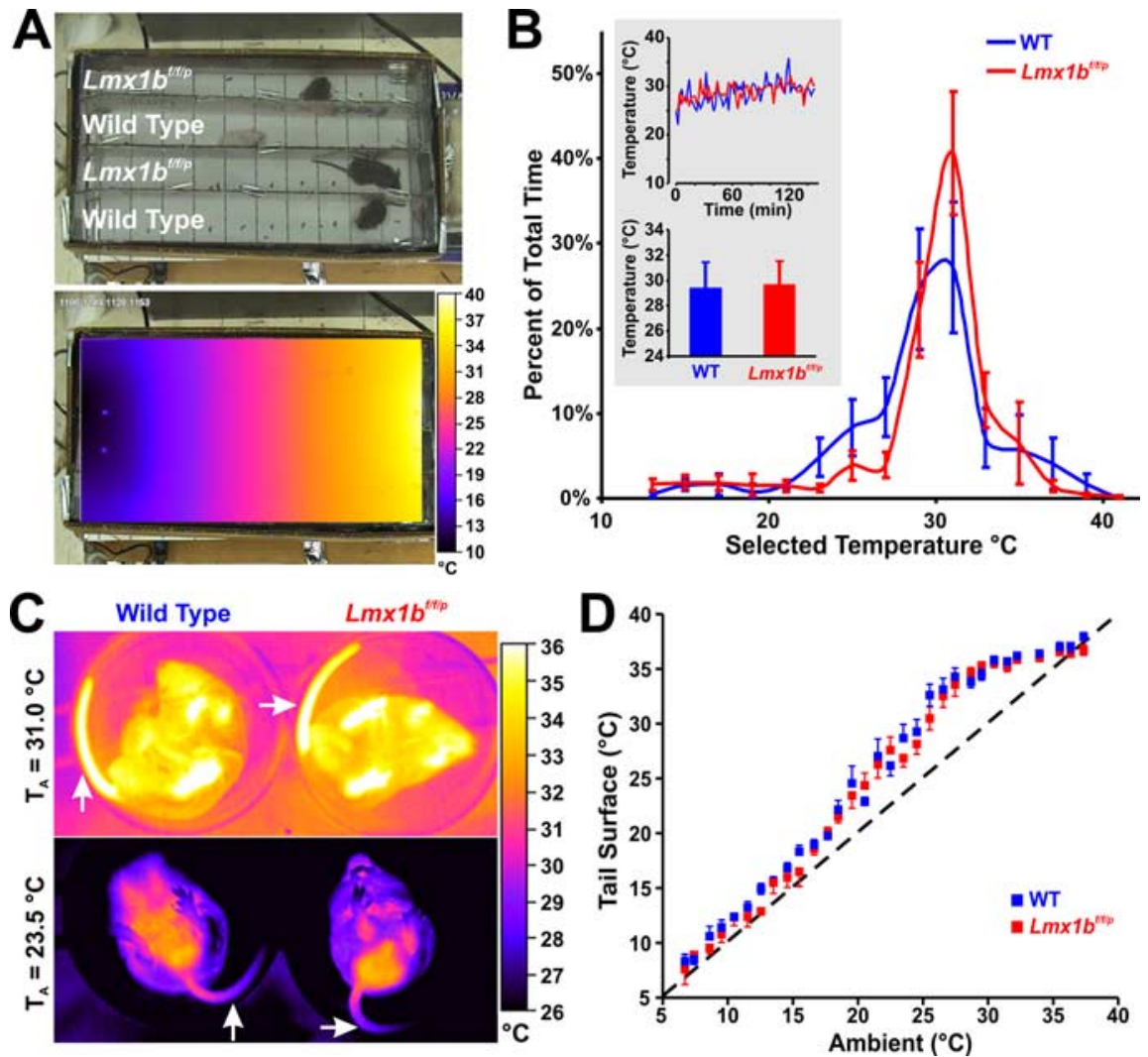

Figure 4. $L m \times 1 b^{f f f / p}$ mice have normal thermosensory perception and activate heat conservation mechanisms normally in response to cold. $\boldsymbol{A}$, Visible light (top) and infrared (bottom) images of thermocline. $\boldsymbol{B}$, Summary data from thermocline experiments $\left(n=5 \mathrm{WT}, 6 \mathrm{Lm} \times 1 b^{f / f / p}\right)$. Note that the mean temperature that mice selected over time (top inset) and overall (bottom inset) were not different between genotypes. $\boldsymbol{C}$, Thermographic images of tail (arrows) surface temperatures in WT (left) and $L m \times 1 b^{f f f / p}$ (right) mice. $\boldsymbol{D}$, Summary data of tail surface temperature versus ambient temperature when mice were exposed to cold $\left(n=10 \mathrm{WT}, 8 \mathrm{Lm} \times 1 b^{\mathrm{f} / \mathrm{f} / \mathrm{p}}\right)$. Data are mean \pm SEM.

\section{Rescue of ventilatory deficit with}

intracerebroventricular 5-HT

To determine whether intracerebroventricular infusion of 5-HT could reverse the attenuated HCVR or thermogenic response to cold, we implanted cannulas into the lateral ventricles of a second set of $L m x 1 b^{f / f / p}$ mice. For these studies, we measured baseline ventilation in normoxia and hyperoxia, the hypoxic ventilatory response, and the HCVR in hyperoxia. At baseline (before i.c.v cannulation), there was significant attenuation of breathing frequency, ventilatory drive and the HCVR in $L m \times 1 b^{f / f / p}$ mice compared with WT mice (Fig. 6A,B), as seen in our previous dataset (Table 1, Fig. $2 A-C$ ). Intracerebroventricular infusion of Ringers with no 5 -HT, or 1 or $100 \mu \mathrm{M} 5$-HT had no effect on baseline ventilation or the HCVR in $L m \times 1 b^{f / f / p}$ mice relative to preinfusion control (data not shown). However, intracerebroventricular infusion of Ringer with $0.5,1$, and $5 \mathrm{~mm} 5$-HT increased baseline ventilation in normoxia (Fig. $6 B$, inset), and 1 and $5 \mathrm{~mm}$ 5 -HT increased baseline ventilation in hyperoxia (Fig. 6B). Additionally, 1 and $5 \mathrm{~mm}$ 5-HT significantly increased baseline frequency and ventilatory drive in $L m \times 1 b^{f / f / p}$ mice, so that these parameters were equal to those seen in WT mice (data not shown). We also found a dose-dependent augmentation of the hyperoxic HCVR in $L m \times 1 b^{f / f / p}$ mice with intracerebroventricular 5-HT, where 1 and $5 \mathrm{~mm}$ 5-HT fully restored the HCVR to WT levels (Fig. 6B).

In contrast to the restoration of the HCVR, we found no effect of intracerebroventricular 5-HT infusion on the hypoxic ventila- tory response, where $V_{\mathrm{E}} / V_{\mathrm{O}_{2}}$ in $L m \times 1 b^{f / f / p}$ mice increased to $180.0 \pm 9.3 \%, 174.4 \pm$ $9.7 \%$, and $183.4 \pm 12.1 \%$ of control in response to hypoxia with 0,1 , and $5 \mathrm{~mm}$ 5-HT, respectively. Additionally, intracerebroventricular 5-HT infusion did not reverse the cold-induced hypothermia during exposure to $4^{\circ} \mathrm{C}$ in $L m \times 1 b^{f / f / p}$ mice at all concentrations of infused intracerebroventricular 5-HT (Fig. 6C). In fact, intracerebroventricular 5-HT infusion caused a trend toward exacerbation of the coldinduced hypothermia ( $p=0.095)$, which would be consistent with a 5-HT neuronindependent effect of $5-\mathrm{HT}_{1 \mathrm{~A}}$ receptormediated inhibition of cold-induced vasoconstriction (Ootsuka and Blessing, 2006).

The rescue effects on breathing frequency, ventilatory drive and the HCVR indicate that there are functional 5-HT receptors in $L m \times 1 b^{f / f / p}$ mice despite complete 5-HT neuron loss, consistent with previous evidence using in situ hybridization and immunohistochemistry (Zhao et al., 2007). Clearly, intracerebroventricular 5-HT reached brainstem respiratory and/or spinal motor neurons, but we cannot exclude the possibility that our negative result in thermogenic rescue was because of an inability of intracerebroventricular 5-HT to reach the thermogenic effector neurons (Madden and Morrison, 2006). Additionally, we estimate the effective CSF concentrations of 5-HT to be 55-275 $\mu \mathrm{M}$, based on a CSF production rate of $18 \mu \mathrm{l} / \mathrm{h}$ (Oshio et al., 2005), and an infusion rate of $1.0 \mu \mathrm{l} / \mathrm{h}$. This estimated CSF concentration is likely higher than tissue levels, but it is not clear how much higher. There is a loss of expression of the serotonin transporter in $L m \times 1 b^{f / f / p}$ mice (Zhao et al., 2006), so there would be less uptake of 5-HT than in WT mice. Therefore, this estimate is probably reasonably accurate for bulk CSF, and provides an upper limit of the 5-HT concentration within the brain parenchyma. It is thus unclear whether the 5-HT concentration needed to enhance the HCVR is physiological or not.

\section{Discussion}

The data presented here from this unique animal model point to a major role for 5-HT neurons in the hypercapnic ventilatory response and cold-induced thermogenesis. Near-complete 5-HT neuron loss in adult $L m \times 1 b^{f / f / p}$ mice does not affect baseline ventilation or the hypoxic ventilatory response, but results in a $50 \%$ deficit in the hypercapnic ventilatory response. Temperature control is normal under baseline conditions, and there is normal thermosensory perception and heat conservation in response to cold exposure. However, these mice develop severe hypothermia during a cold challenge as a result of a defect in heat generation, and this is because of inability to sustain normal shivering and BAT activation. In addition, these data indicate that exogenous 5-HT stimulates baseline ventilation and reverses the blunted hypercapnic ventilatory response in $L m \times 1 b^{f / f / p}$ mice, pointing to a previously unrecognized role of central 5-HT in increasing the gain of the respiratory network to hypercapnia. 
A
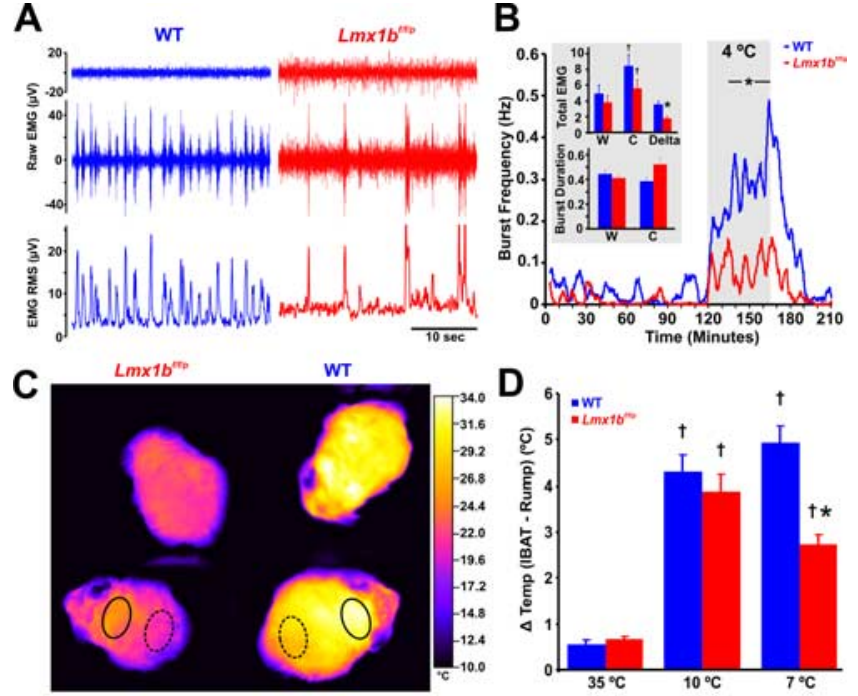

E
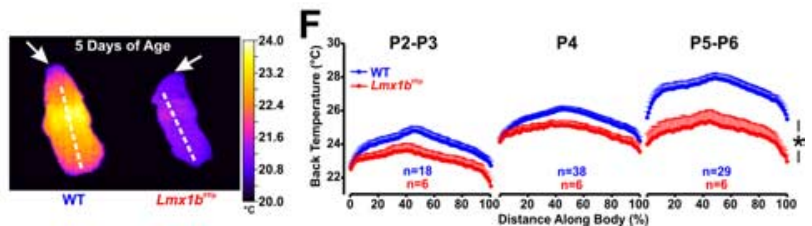

Figure 5. Shivering and brown adipose tissue activation are both impaired in $L m \times 1 b^{f / f / p}$ mice. $\boldsymbol{A}$, Recordings of nuchal muscle activity (top two traces, raw data; bottom trace, RMS) in warm (top trace; $28^{\circ} \mathrm{C}$ ) and cold (bottom two traces; $4^{\circ} \mathrm{C}$ ) $T_{\text {Amb }}$. Note that regular shivering was induced by cold exposure in the WT mouse (left; blue), but bursts were less frequent in the $L m \times 1 b^{f / f / p}$ mouse (right; red). $\boldsymbol{B}$, Group means ( $n=4 \mathrm{WT}$, blue; $4 L m \times 1 b^{f / f / p}$, red) of burst frequency before, during and after cold exposure. Insets, Total nuchal muscle activity (top; expressed as absolute and $\Delta$ total EMG), and burst duration (bottom) $1 \mathrm{~h}$ before [warm (W)] and during the last $30 \mathrm{~min}$ of cold exposure [cold (C)]. C, Thermographic images of the shaved back in WT (right) and $L m \times 1 b^{f / f / p}$ (left) mice during cold exposure. D, Summary data of surface temperature differences between the IBAT region (solid circles in $\boldsymbol{C}$ ) and the lower back (dashed circles in $C$ ) at $T_{\text {Amb }}$ of 35,10 , and $7^{\circ} \mathrm{C}$. Note that there was significant IBAT activation in both WT $(n=8)$ and $L m \times 1 b^{f / f / p}(n=8)$ mice at 10 and $7^{\circ} \mathrm{C}$, but the activation was less in $L m \times 1 b^{f / f / p}$ mice at $7^{\circ} \mathrm{C}$. E, Thermographic image of neonatal (P5) WT and $L m \times 1 b^{f / f / p}$ mice at $T_{\text {Amb }}$ of $20^{\circ}$. Arrows denote the head. $\boldsymbol{F}$, Line profile summary data of back surface temperatures at three ages (P2-P3, P4, and P5-P6). Note the visible yellow (warm) band in the P5 WT mouse, indicating IBAT activation. Two-way ANOVA (genotype and time, or ambient temperature, and tail surface temperature as factors) or unpaired $t$ test was used; ${ }^{\dagger} p<0.05$ for warm versus cold; ${ }^{*} p<0.05$ for WT versus $L m \times 1 b^{f / f / p}$. Data are mean \pm SEM.

\section{Role of central 5-HT neurons in respiratory control}

Previous reports investigating the role of 5-HT and/or serotonergic neurons in control of breathing have relied on either pharmacologic approaches, including 5-HT depleting agents such as PCPA, or 5-HT neuron-specific lesions using agents such as 5,7dihyroxytryptamine (5,7-DHT). However, these approaches have been difficult to interpret, and in some cases have produced contradictory results. For example, PCPA induces a substantial increase in baseline ventilation, but has no effect on the HCVR leading to the conclusion that 5-HT inhibits breathing at rest (Olson et al., 1979; Mitchell et al., 1983; Annerbrink et al., 2003). However, 5,7-DHT induces hypoventilation at rest (Olson et al., 1979) and during hypercapnia (Mueller et al., 1984), leading to the opposite conclusion - that 5-HT stimulates breathing at rest and during hypercapnia.

The reasons for these contradictory results are not clear, but there are several possible explanations. Whereas PCPA is very effective in depleting central 5-HT, it can also deplete peripheral 5-HT (Koe and Weissman, 1966) and other monoamines (Reader and Gauthier, 1984; Dailly et al., 2006), and does not
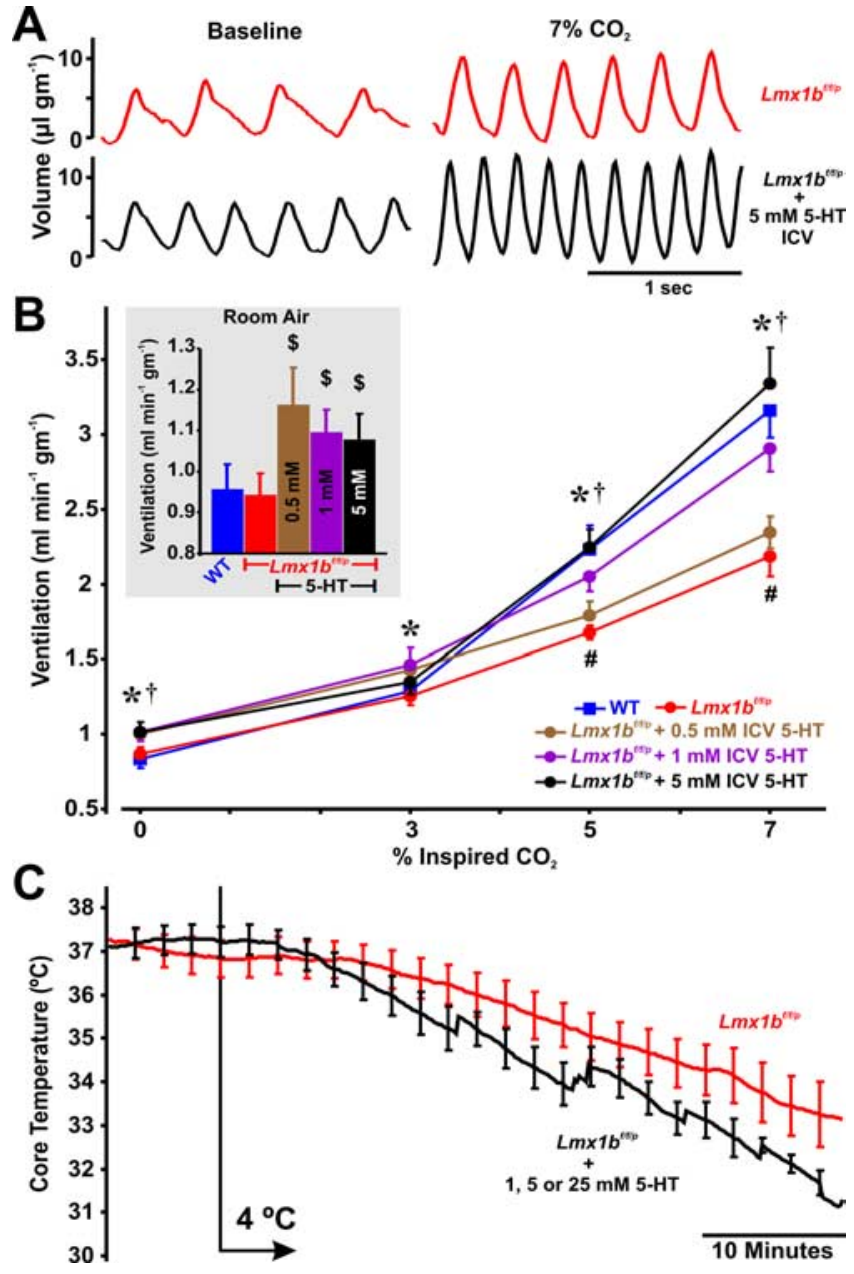

Figure 6. Exogenous 5-HT rescues the hypercapnic ventilatory response. $A$, Plethysmography recordings from an $\mathrm{Lm} \times 1 \mathrm{~b}^{\mathrm{fff/p}}$ mouse breathing $0 \% \mathrm{CO}_{2}$ and $7 \% \mathrm{CO}_{2}$ (both in $50 \% \mathrm{O}_{2}$ ) before (red), and on the second day of intracerebroventricular infusion of $5 \mathrm{~mm} 5-\mathrm{HT}$ (black). $\boldsymbol{B}$, Effect of $\mathrm{CO}_{2}$ on ventilation in WT mice (blue; $n=7$ ), $L m \times 1 b^{f f / p}$ mice before intracerebroventricular infusion (red; $n=9$ ), and $L m \times 1 b^{f / f / p}$ mice on the second day of intracerebroventricular infusion of 5 -HT at concentrations (within the pump) of 0.5 (brown; $n=5$ ), 1.0 (purple; $n=7$ ), and 5.0 $\mathrm{mm}($ black; $n=6)$. Data were obtained in $50 \% 0_{2}$. Inset, Baseline ventilation in $21 \% \mathrm{O}_{2}$. C, Mean $T_{\text {core }}$ in $L m \times 1 b^{f f f / p}$ mice with (black) or without (red) intracerebroventricular 5-HT infusion. Data were combined from all animals at 5-HT concentrations of 1, 5, and $25 \mathrm{~mm}$. Two-way ANOVA ( $p<0.001$ for 5 -HT level and condition), and unpaired $t$ test were used; ${ }^{5} p<0.05$ for intracerebroventricular 5 -HT versus control; ${ }^{*} p<0.05$ for $1.0 \mathrm{~mm} 5$ - HT versus control; ${ }^{\dagger} p<$ 0.05 for $5.0 \mathrm{~mm} 5$-HT versus control; ${ }^{\#} p<0.05$ for $L m \times 1 b^{f / f / p}$ control and $0.5 \mathrm{~mm} 5$-HT versus WT. Data are mean \pm SEM.

affect neuropeptides colocalized in 5-HT neurons, such as thyrotropin-releasing hormone and substance P (Walker et al., 1990; Przegalinski et al., 1992). Possibly for these reasons, data obtained using PCPA have contributed previously to erroneous conclusions about the role of 5-HT in sleep (Jouvet, 1999). The advantage of 5,7-DHT is that it eliminates 5-HT neurons, and thus blocks release of both 5-HT and neuropeptides. The disadvantage is that 5,7-DHT typically reaches only a limited number of 5-HT neurons (Penatti et al., 2006). Therefore, data obtained using either of these approaches can be difficult to interpret.

$L m \times 1 b^{f / f / p}$ mice offer advantages over these other methods. Unlike PCPA, this genetic model leads to loss of both 5-HT and the neuropeptides colocalized within central 5-HT neurons, and it is much more effective than 5,7-DHT in eliminating nearly all 5-HT neurons (Zhao et al., 2006; Zhao et al., 2007). Although compensatory mechanisms are likely to occur during develop- 
ment, which may reduce the defects that result from loss of 5-HT, this model remains a valuable approach to determine the relative importance of 5-HT neurons for breathing at rest and during respiratory challenges with hypoxia and hypercapnia. We found relatively few effects on baseline breathing and the hypoxic ventilatory response, but a significantly blunted hypercapnic ventilatory response.

\section{Contribution of 5-HT neurons to the hypercapnic ventilatory response}

There is strong evidence that 5-HT neurons are respiratory $\mathrm{CO}_{2}$ chemoreceptors, including increased firing rate of 5-HT neurons and 5-HT release during hypercapnia (Veasey et al., 1995; Richerson, 2004; Kanamaru and Homma, 2007). However, the relative contribution of 5-HT neurons to the HCVR compared with other putative chemoreceptors (Mulkey et al., 2004; Putnam et al., 2004) remains unclear (Guyenet et al., 2005; Richerson et al., 2005). The current data do not directly address the important question of whether 5-HT neurons are respiratory $\mathrm{CO}_{2}$ chemoreceptors, but they do address two related and previously unanswered issues. First, our data unequivocally show that a ventilatory response to $\mathrm{CO}_{2}$ can occur in the absence of 5-HT neurons, even after suppression of peripheral chemoreceptors with high $\mathrm{O}_{2}$, supporting the conclusion that there are nonserotonergic CNS neurons that are central chemoreceptors. There is, however, a greater contribution of 5-HT neurons to the HCVR than was previously recognized (Nattie, 2001). Second, they demonstrate that 5-HT plays a previously unrecognized role in the HCVR. Increasing brain 5-HT levels with intracerebroventricular infusion completely rescued the HCVR in $L m \times 1 b^{f / f / p}$ mice. This indicates that activation of 5-HT receptors on nonserotonergic neurons can enhance the responsiveness of the respiratory network to changes in $\mathrm{CO}_{2} / \mathrm{pH}$.

Neuromodulatory effects of 5-HT, acting on respiratory neurons that govern rhythm and pattern generation and/or respiratory motor neurons, could conceivably contribute to the effects of intracerebroventricular 5-HT observed in the current study. This, however, would likely enhance respiratory output under all conditions, including during a hypoxic challenge. Conversely, 5-HT may specifically enhance the HCVR by either increasing the gain of respiratory neurons to input from chemoreceptors, or by enhancing the activity of nonserotonergic chemoreceptors (Putnam et al., 2004; Li et al., 2006; Mulkey et al., 2007). The effects of 5-HT on breathing demonstrated here could also potentially be mediated in part by trophic effects (Golder and Mitchell, 2005), or by 5-HT-dependent respiratory plasticity (Feldman et al., 2003). The design of our experiments do not allow us to determine whether intracerebroventricular 5-HT acts via neuromodulation, synaptic plasticity and/or trophic effects, nor do they delineate the site of action of intracerebroventricular 5-HT within the respiratory network. However, any explanation of the mechanisms involved must take into account the selective effect of 5-HT on respiratory frequency, ventilatory drive and the HCVR, without effects on tidal volume or the hypoxic ventilatory response.

\section{Integration of respiratory and thermoregulatory control}

The medial preoptic/anterior hypothalamus (POAH) and dorsomedial nucleus of the hypothalamus, periaqueductal gray matter of the midbrain, and the nucleus raphé pallidus are all involved in thermoregulation (Boulant, 2000). It has been less clear whether the neurons within the raphé pallidus that are involved are those that contain 5-HT (Morrison, 2004b). Our data support the conclusion that 5-HT neurons are not required for low levels of cold-induced shivering and IBAT activation, but neither of these heat-generating mechanisms can operate at their full capacity in $L m \times 1 b^{f / f / p}$ mice. In contrast, cold-induced peripheral vasoconstrictor responses were normal. These observations are consistent with the conclusion that 5-HT neurons modulate descending synaptic drive from the hypothalamus to effector organs involved in thermogenesis, but are not part of the direct pathway for either heat generation or conservation (Nason and Mason, 2006).

Given the evidence suggesting roles for serotonergic neurons and 5-HT in both thermoregulation and respiratory control, we suggest that these neurons may serve to coordinate ventilatory and metabolic demands, similar to the postulated integrative role of hypothalamic neurons. For example, the POAH contains warm-sensitive neurons (Griffin et al., 1996) that receive afferent inputs from skin and spinal thermoreceptors (Boulant and Hardy, 1974). These warm-sensitive POAH neurons are also $\mathrm{CO}_{2}$ sensitive (Wright and Boulant, 2007). Likewise, orexinergic neurons in the lateral hypothalamus are involved in feeding, arousal and ventilatory control, and are also $\mathrm{CO}_{2}$ sensitive (Williams et al., 2007), and orexin-null mice exhibit a substantially blunted HCVR (Deng et al., 2007). Similarly, raphé 5-HT neurons respond to central (Nason and Mason, 2006) and peripheral (Martin-Cora et al., 2000) cooling and augment cold-induced thermogenesis, facilitate respiratory rhythm generation (Pena and Ramirez, 2002) and respiratory motor output (Brandes et al., 2006), and play a major role in ventilatory control during hypercapnia. These and other observations point to both the hypothalamus and 5-HT system as likely sites for integration of thermoregulatory, metabolic, and respiratory control, as previously suggested (Hinrichsen et al., 1998). We conclude that these systems might act in parallel or cooperatively to maintain blood gas homeostasis relative to metabolic demand and body temperature maintenance requirements.

\section{Relevance to physiology and disease}

The deficits reported here from mice with near-complete absence of 5-HT neurons provide insight into the normal role of the 5-HT system. The contributions and relative importance of the 5-HT system in respiratory and thermoregulatory control may be underestimated in this model, likely because of developmental and/or other compensatory mechanisms. However, our results indicate that mice can maintain normal ventilatory and thermoregulatory homeostasis at baseline in the absence of 5-HT neurons. However, they are unable to adequately respond to some environmental challenges, such as a rise in $\mathrm{CO}_{2}$ or a drop in ambient temperature. Thus, the 5-HT system may be very important for responding to these exogenous stressors, so that a defect in this system could compromise a vulnerable individual. These observations may be relevant to sudden infant death syndrome, which has previously been linked to abnormalities in the 5-HT system (Paterson et al., 2006), and has been associated with defects in control of body temperature and breathing (Shannon et al., 1977; Hunt et al., 1981; Dunne and Matthews, 1988).

\section{References}

Annerbrink K, Olsson M, Melchior LK, Hedner J, Eriksson E (2003) Serotonin depletion increases respiratory variability in freely moving rats: implications for panic disorder. Int J Neuropsychopharmacol 6:51-56.

Baker-Herman TL, Mitchell GS (2002) Phrenic long-term facilitation requires spinal serotonin receptor activation and protein synthesis. J Neurosci 22:6239-6246. 
Baker-Herman TL, Fuller DD, Bavis RW, Zabka AG, Golder FJ, Doperalski NJ, Johnson RA, Watters JJ, Mitchell GS (2004) BDNF is necessary and sufficient for spinal respiratory plasticity following intermittent hypoxia. Nat Neurosci 7:48-55.

Boulant JA (2000) Role of the preoptic-anterior hypothalamus in thermoregulation and fever. Clin Infect Dis 31 [Suppl 5]:S157-S161.

Boulant JA (2006) Neuronal basis of Hammel's model for set-point thermoregulation. J Appl Physiol 100:1347-1354.

Boulant JA, Hardy JD (1974) The effect of spinal and skin temperatures on the firing rate and thermosensitivity of preoptic neurones. J Physiol (Lond) 240:639-660.

Brandes IF, Zuperku EJ, Stucke AG, Jakovcevic D, Hopp FA, Stuth EA (2006) Serotonergic modulation of inspiratory hypoglossal motoneurons in decerebrate dogs. J Neurophysiol 95:3449-3459.

Cano G, Passerin AM, Schiltz JC, Card JP, Morrison SF, Sved AF (2003) Anatomical substrates for the central control of sympathetic outflow to interscapular adipose tissue during cold exposure. J Comp Neurol 460:303-326.

Cooper KE, Veale WL (1986) Effects of temperature on breathing. In: Handbook of physiology, Sec 3, The respiratory system, Vol II, Control of breathing (Cherniack NS, Widdicombe JG, eds), pp 691-702. Bethesda, MD: American Physiological Society.

Dailly E, Chenu F, Petit-Demouliere B, Bourin M (2006) Specificity and efficacy of noradrenaline, serotonin depletion in discrete brain areas of Swiss mice by neurotoxins. J Neurosci Methods 150:111-115.

Deng BS, Nakamura A, Zhang W, Yanagisawa M, Fukuda Y, Kuwaki T (2007) Contribution of orexin in hypercapnic chemoreflex: Evidence from genetic and pharmacological disruption and supplementation studies in mice. J Appl Physiol.

Dimicco JA, Zaretsky DV (2007) The dorsomedial hypothalamus: a new player in thermoregulation. Am J Physiol Regul Integr Comp Physiol 292:R47-R63.

Drorbaugh JE, Fenn WO (1955) A barometric method for measuring ventilation in newborn infants. Pediatrics 16:81-87.

Dunne KP, Matthews TG (1988) Hypothermia and sudden infant death syndrome. Arch Dis Child 63:438-440.

Erickson JT, Shafer G, Rossetti MD, Wilson CG, Deneris ES (2007) Arrest of 5HT neuron differentiation delays respiratory maturation and impairs neonatal homeostatic responses to environmental challenges. Respir Physiol Neurobiol 159:85-101.

Feldman JL, Mitchell GS, Nattie EE (2003) Breathing: rhythmicity, plasticity, chemosensitivity. Annu Rev Neurosci 26:239-266.

Frappell PB, Dotta A, Mortola JP (1992) Metabolism during normoxia, hyperoxia, and recovery in newborn rats. Can J Physiol Pharmacol 70:408-411.

Golder FJ, Mitchell GS (2005) Spinal synaptic enhancement with acute intermittent hypoxia improves respiratory function after chronic cervical spinal cord injury. J Neurosci 25:2925-2932.

Gordon CJ (1985) Relationship between autonomic and behavioral thermoregulation in the mouse. Physiol Behav 34:687-690.

Griffin JD, Kaple ML, Chow AR, Boulant JA (1996) Cellular mechanisms for neuronal thermosensitivity in the rat hypothalamus. J Physiol (Lond) 492:231-242.

Guyenet PG, Stornetta RL, Bayliss DA, Mulkey DK (2005) Retrotrapezoid nucleus: a litmus test for the identification of central chemoreceptors. Exp Physiol 90:247-253.

Haxhiu MA, Tolentino-Silva F, Pete G, Kc P, Mack SO (2001) Monoaminergic neurons, chemosensation and arousal. Respir Physiol 129:191-209.

Hinrichsen CF, Maskrey M, Mortola JP (1998) Ventilatory and metabolic responses to cold and hypoxia in conscious rats with discrete hypothalamic lesions. Respir Physiol 111:247-256.

Hodges MR, Martino P, Davis S, Opansky C, Pan LG, Forster HV (2004a) Effects on breathing of focal acidosis at multiple medullary raphe sites in awake goats. J Appl Physiol 97:2303-2309.

Hodges MR, Opansky C, Qian B, Davis S, Bonis J, Bastasic J, Leekley T, Pan LG, Forster HV (2004b) Transient attenuation of CO2 sensitivity after neurotoxic lesions in the medullary raphe area of awake goats. J Appl Physiol 97:2236-2247.

Hoffman JM, Brown JW, Sirlin EA, Benoit AM, Gill WH, Harris MB, Darnall RA (2007) Activation of 5-HT1A receptors in the paragigantocellularis lateralis decreases shivering during cooling in the conscious piglet. Am J Physiol Regul Integr Comp Physiol.
Hunt CE, McCulloch K, Brouillette RT (1981) Diminished hypoxic ventilatory responses in near-miss sudden infant death syndrome. J Appl Physiol 50:1313-1317.

Huttunen P, Lapinlampi T, Myers RD (1988) Temperature-related release of serotonin from unrestrained rats' pre-optic area perfused with ethanol. Alcohol 5:189-193.

Ivanov PC, Rosenblum MG, Peng CK, Mietus J, Havlin S, Stanley HE, Goldberger AL (1996) Scaling behaviour of heartbeat intervals obtained by wavelet-based time-series analysis. Nature 383:323-327.

Johnson PL, Hollis JH, Moratalla R, Lightman SL, Lowry CA (2005) Acute hypercarbic gas exposure reveals functionally distinct subpopulations of serotonergic neurons in rats. J Psychopharmacol 19:327-341.

Jouvet M (1999) Sleep and serotonin: an unfinished story. Neuropsychopharmacology 21:24S-27S.

Kanamaru M, Homma I (2007) Compensatory airway dilation and additive ventilatory augmentation mediated by dorsomedial medullary 5-hydroxytryptamine 2 receptor activity and hypercapnia. Am J Physiol Regul Integr Comp Physiol 293:R854-R860.

Koe BK, Weissman A (1966) p-Chlorophenylalanine: a specific depletor of brain serotonin. J Pharmacol Exp Ther 154:499-516.

Lahiri S, DeLaney RG (1975) Stimulus interaction in the responses of carotid body chemoreceptor single afferent fibers. Respir Physiol 24:249-266.

Lalley PM (1986) Serotoninergic and non-serotoninergic responses of phrenic motoneurones to raphe stimulation in the cat. J Physiol (Lond) 380:373-385.

Larkman PM, Kelly JS (1992) Ionic mechanisms mediating 5-hydroxytryptamine- and noradrenaline-evoked depolarization of adult rat facial motoneurones. J Physiol (Lond) 456:473-490.

Larnicol N, Wallois F, Berquin P, Gros F, Rose D (1994) c-fos-like immunoreactivity in the cat's neuraxis following moderate hypoxia or hypercapnia. J Physiol (Paris) 88:81-88.

Li A, Zhou S, Nattie E (2006) Simultaneous inhibition of caudal medullary raphé and retrotrapezoid nucleus decreases breathing and the $\mathrm{CO}_{2}$ response in conscious rats. J Physiol (Lond) 577:307-318.

Madden CJ, Morrison SF (2006) Serotonin potentiates sympathetic responses evoked by spinal NMDA. J Physiol (Lond) 577:525-537.

Manzke T, Guenther U, Ponimaskin EG, Haller M, Dutschmann M, Schwarzacher S, Richter DW (2003) 5-HT4(a) receptors avert opioid-induced breathing depression without loss of analgesia. Science 301:226-229.

Martin-Cora FJ, Fornal CA, Metzler CW, Jacobs BL (2000) Single-unit responses of serotonergic medullary and pontine raphe neurons to environmental cooling in freely moving cats. Neuroscience 98:301-309.

Mitchell GS, Smith CA, Vidruk EH, Jameson LC, Dempsey JA (1983) Effects of p-chlorophenylalanine on ventilatory control in goats. J Appl Physiol 54:277-283.

Morrison SF (2004a) Activation of 5-HT1A receptors in raphe pallidus inhibits leptin-evoked increases in brown adipose tissue thermogenesis. Am J Physiol Regul Integr Comp Physiol 286:R832-R837.

Morrison SF (2004b) Central pathways controlling brown adipose tissue thermogenesis. News Physiol Sci 19:67-74.

Mortola JP, Frappell PB (1998) On the barometric method for measurements of ventilation, and its use in small animals. Can J Physiol Pharmacol 76:937-944.

Mueller RA, Towle AC, Breese GR (1984) Supersensitivity to the respiratory stimulatory effect of TRH in 5,7-dihydroxytryptamine-treated rats. Brain Res 298:370-373.

Mulkey DK, Stornetta RL, Weston MC, Simmons JR, Parker A, Bayliss DA, Guyenet PG (2004) Respiratory control by ventral surface chemoreceptor neurons in rats. Nat Neurosci 7:1360-1369.

Mulkey DK, Rosin DL, West G, Takakura AC, Moreira TS, Bayliss DA, Guyenet PG (2007) Serotonergic neurons activate chemosensitive retrotrapezoid nucleus neurons by a $\mathrm{pH}$-independent mechanism. J Neurosci 27:14128-14138.

Nason Jr MW, Mason P (2006) Medullary raphe neurons facilitate brown adipose tissue activation. J Neurosci 26:1190-1198.

Nattie EE (2001) Central chemosensitivity, sleep, and wakefulness. Respir Physiol 129:257-268.

Nattie EE, Li A, Richerson G, Lappi DA (2004) Medullary serotonergic neurones and adjacent neurones that express neurokinin-1 receptors are both involved in chemoreception in vivo. J Physiol (Lond) 556:235-253. 
Olson Jr EB, Dempsey JA, McCrimmon DR (1979) Serotonin and the control of ventilation in awake rats. J Clin Invest 64:689-693.

Ootsuka Y, Blessing WW (2003) 5-Hydroxytryptamine 1A receptors inhibit cold-induced sympathetically mediated cutaneous vasoconstriction in rabbits. J Physiol (Lond) 552:303-314.

Ootsuka Y, Blessing WW (2006) Activation of 5-HT1A receptors in rostral medullary raphe inhibits cutaneous vasoconstriction elicited by cold exposure in rabbits. Brain Res 1073-1074:252-261.

Oshio K, Watanabe H, Song Y, Verkman AS, Manley GT (2005) Reduced cerebrospinal fluid production and intracranial pressure in mice lacking choroid plexus water channel Aquaporin-1. FASEB J 19:76-78.

Pace RW, Mackay DD, Feldman JL, Del Negro CA (2007) Role of persistent sodium current in mouse preBotzinger Complex neurons and respiratory rhythm generation. J Physiol (Lond) 580:485-496.

Pack AI, Galante RJ, Maislin G, Cater J, Metaxas D, Lu S, Zhang L, Von SR, Kay T, Lian J, Svenson K, Peters LL (2007) Novel method for highthroughput phenotyping of sleep in mice. Physiol Genomics 28:232-238.

Paterson DS, Trachtenberg FL, Thompson EG, Belliveau RA, Beggs AH, Darnall R, Chadwick AE, Krous HF, Kinney HC (2006) Multiple serotonergic brainstem abnormalities in sudden infant death syndrome. JAMA 296:2124-2132.

Pena F, Ramirez JM (2002) Endogenous activation of serotonin-2A receptors is required for respiratory rhythm generation in vitro. J Neurosci 22:11055-11064.

Penatti EM, Berniker AV, Kereshi B, Cafaro C, Kelly ML, Niblock MM, Gao HG, Kinney HC, Li A, Nattie EE (2006) Ventilatory response to hypercapnia and hypoxia after extensive lesion of medullary serotonergic neurons in newborn conscious piglets. J Appl Physiol 101:1177-1188.

Przegalinski E, Jaworska L, Golembiowska K (1992) The effect of p-chloroamphetamine and p-chlorophenylalanine on the level of thyrotropin-releasing hormone and its receptors in some brain structures and lumbar spinal cord of the rat. Neuropeptides 23:19-25.

Putnam RW, Filosa JA, Ritucci NA (2004) Cellular mechanisms involved in $\mathrm{CO}(2)$ and acid signaling in chemosensitive neurons. Am J Physiol Cell Physiol 287:C1493-C1526.

Reader TA, Gauthier P (1984) Catecholamines and serotonin in the rat central nervous system after 6-OHDA, 5-7-DHT and p-CPA. J Neural Transm 59:207-227.

Rekling JC, Funk GD, Bayliss DA, Dong XW, Feldman JL (2000) Synaptic control of motoneuronal excitability. Physiol Rev 80:767-852.

Richerson GB (1995) Response to CO2 of neurons in the rostral ventral medulla in vitro. J Neurophysiol 73:933-944.

Richerson GB (2004) Serotonergic neurons as carbon dioxide sensors that maintain pH homeostasis. Nat Rev Neurosci 5:449-461.
Richerson GB, Wang W, Tiwari J, Bradley SR (2001) Chemosensitivity of serotonergic neurons in the rostral ventral medulla. Respir Physiol 129:175-189.

Richerson GB, Wang W, Hodges MR, Dohle CI, Diez-Sampedro A (2005) Homing in on the specific phenotype(s) of central respiratory chemoreceptors. Exp Physiol 90:259-266.

Severson CA, Wang W, Pieribone VA, Dohle CI, Richerson GB (2003) Midbrain serotonergic neurons are central $\mathrm{pH}$ chemoreceptors. Nat Neurosci 6:1139-1140.

Shannon DC, Kelly DH, O’Connell K (1977) Abnormal regulation of ventilation in infants at risk for sudden-infant-death syndrome. N Engl J Med 297:747-750.

Taylor NC, Li A, Nattie EE (2005) Medullary serotonergic neurones modulate the ventilatory response to hypercapnia, but not hypoxia in conscious rats. J Physiol (Lond) 566:543-557.

Uchida S, Kitamoto A, Umeeda H, Nakagawa N, Masushige S, Kida S (2005) Chronic reduction in dietary tryptophan leads to changes in the emotional response to stress in mice. J Nutr Sci Vitaminol (Tokyo) 51:175-181.

Veasey SC, Fornal CA, Metzler CW, Jacobs BL (1995) Response of serotonergic caudal raphe neurons in relation to specific motor activities in freely moving cats. J Neurosci 15:5346-5359.

Walker PD, Schotland S, Hart RP, Jonakait GM (1990) Tryptophan hydroxylase inhibition increases preprotachykinin mRNA in developing and adult medullary raphe nuclei. Brain Res Mol Brain Res 8:113-119.

Wang W, Tiwari JK, Bradley SR, Zaykin RV, Richerson GB (2001) Acidosisstimulated neurons of the medullary raphe are serotonergic. J Neurophysiol 85:2224-2235.

Williams RH, Jensen LT, Verkhratsky A, Fugger L, Burdakov D (2007) Control of hypothalamic orexin neurons by acid and CO2. Proc Natl Acad Sci USA 104:10685-10690.

Wright CL, Boulant JA (2007) Carbon dioxide and $\mathrm{pH}$ effects on temperature-sensitive and -insensitive hypothalamic neurons. J Appl Physiol 102:1357-1366.

Zhao ZQ, Chiechio S, Sun YG, Zhang KH, Zhao CS, Scott M, Johnson RL, Deneris ES, Renner KJ, Gereau RW, Chen ZF (2007) Mice lacking central serotonergic neurons show enhanced inflammatory pain and an impaired analgesic response to antidepressant drugs. J Neurosci 27:6045-6053.

Zhao ZQ, Scott M, Chiechio S, Wang JS, Renner KJ, Gereau RW, Johnson RL, Deneris ES, Chen ZF (2006) Lmxlb is required for maintenance of central serotonergic neurons and mice lacking central serotonergic system exhibit normal locomotor activity. J Neurosci 26:12781-12788. 